Timofeeva I. B., Netreba M. M., Moiseienko R. M., Khadzhinova I. V.

\title{
ESSENTIAL CHARACTERISTICS OF THE USE OF INNOVATIVE TECHNOLOGIES IN EDUCATIONAL INSTITUTIONS OF THE NEW UKRAINIAN SCHOOL
}

The usage of innovative technologies in the management of general secondary education is disclosed in the article; the introduction of innovative technologies in the management of the head of the educational institution is justified. Management problems to ensure the quality of educational services are highlighted in the article and the essential characteristics of the introduction of innovative technologies in the educational institution are reviewed. The content and tools of effective innovative management technologies in educational institutions are characterized: forecasting, stimulating teachers, changing the structure of the school, complex problem solving and more.

Decentralization of the school management process is important step in the introduction of innovative management technologies. Productive application of innovations in the management of an educational institution is the participation in international projects. After conducting a survey, it was proved that the usage of innovative management technologies by the head of the educational institution requires a thorough study of the innovative potential of teachers and the features of innovative management of educational institutions. There is an urgent need for the use of innovative technologies in the learning process to ensure the quality of educational services.

The problem of the research is based on a practical approach, in which management innovations are considered as the application of teachers' innovative activity methods to create the image of an educational institution. The usage of the international experience analysis of educational institutions makes it possible to effectively determine the need for the introduction of innovative technologies for the management of educational institutions.

Key words: innovation, innovative technologies, management of educational institution, head of school.

(статтю подано мовою орихіналу)

Among the urgent problems of reforming the education system is the introduction of innovative technologies for the management of educational institutions in the pedagogical field. In the Concept of the implementation of state policy in the field of reforming general secondary education "New Ukrainian School" is clarified: "... The most successful in the labour market in the near future will be professionals who know how to learn throughout life, think critically, set goals and achieve them, work in a team, communicate in a multicultural environment and have other modern skills" [3].

The process of modernization, that takes place in education, requires the intensification of activities and management of the educational institution from the head, who acts as an innovator, who understands the role of science in modern society and is able to evaluate and introduce new technologies into the educational process. A modern professional head of an educational institution is a professional who is ready for innovative activity that will be effective if it takes place in adequate educational forms and solves two interdependent tasks: formation of innovative readiness to perceive innovation and ability to act in a new way.

The management of the New School must correspond to the modern type of society development. It is impossible in modern society, which is multi-vector, applies administrative-command management and total control of the industrial era, this is the main contradiction that leads to the destruction of any social system. The school as an educational system and an object of management is not an exception in this process [1, p. 4].

The purpose of the article is to analyse the essential characteristics of the usage of innovative technologies in educational institutions.

Theoretical aspects of the study are modern researches of the management of general secondary education (L. Danylenko, V. Pikelna, others). They are based on the methodology of pedagogical management (V. Maslov, V. Dragun), in-school management (Y. Konarzhevsky), innovation management (G. Dmitrenko and others), pedagogical innovation (K. Angelovski, M. Potashnyk), management of educational innovations (Z. Ryabova, G. Timoshko), inclusive education (T. But, A. Kolupaeva) and others [5, p. 19].

Management of the educational process in general secondary education requires a common goal to ensure the current level of organization of the educational process and achieve the highest possible quality of education (development, competencies) of pupils and on the basis of such commonality - developing unity of action in each direction of participants in the educational process. Since the head of the educational institution directly manages and organizes the educational process, controls the implementation of educational programs, arranges the activities of the educational institution. The headmaster is responsible for educational, financial, economic and other activities of the institution.

We fully agree with the opinion of A. Romanchuk that innovation in management is the process of making targeted changes aimed at transforming any components in the structure or functioning of organization. The head of the educational institution should have strategic thinking, flexibility, rapid response to changing situations, the ability to make non-standard management decisions, take risks, predict result, select as many alternatives as possible to imply innovation [4, p. 178]. 
Education management plays a critical role in supporting technological progress, which, together with the efforts of heads of educational institutions, are an important addition to the innovative management process. Researches Leger A. and S. Swaminathar singled out the presence of highly educated professionals as a major factor in innovative development. Indeed, in assessing the role of education in innovative development, it should be noted that, on the one hand, it provides technical knowledge and skills to heads of educational institutions and other stakeholders related to the innovation process and the growth of the image of the educational institution. On the other hand, education can stimulate creativity and, thus, simplify the process of adapting innovation to the requirements of real life [6, p. 157].

According to the Organization for Economic Co-operation and Development (OECD), innovation can be interpreted as any technological, scientific, organizational, financial and commercial action required to create, implement and manage new products or improved products and processes [8].

Transparent recruitment, high-quality teachers and goal setting for teachers are crucial for implementation of innovation in educational institutions. Effective leadership and management of an educational institution, as well as academic excellence, are considered the most important criteria for parents, ahead of geographical considerations for choosing an educational institution for children. Any educational institution doesn't work in isolation from other objects, but under the influence of various external factors that create the educational environment. Conditions under which the use of innovative technologies in the management of educational institutions is possible are demonstrated in figure 1.

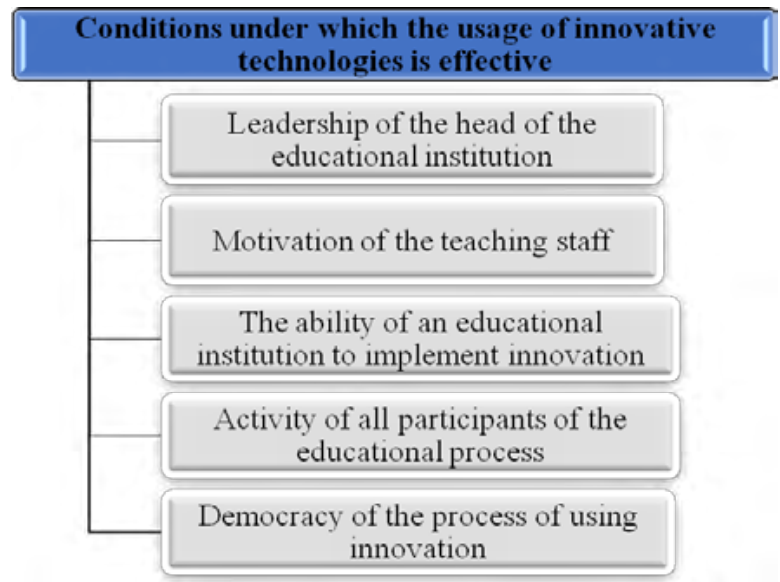

Figure 1. Conditions under which the usage of innovative technologies is effective

Management of the introduction of new technologies involves taking into account the following essential characteristics: purposefulness of the process of technologies implementation; approval among teachers the need to use new technology; organization of technological monitoring of innovation.

The Mariupol Secondary School of I-III grades №52 of the Mariupol City Council of the Donetsk Region was selected as the basis of the study: 925 pupils, including: 242 are children with special needs; 24 children are deprived of parental care; 75 pupils are displaced children from the anti-terrorist operation zone. The decentralization process is an important element in school management: wide delegation of powers, clear and mobile division of powers and responsibilities, management and co-management, involvement of more and more people in the school and community decision-making process. In addition to pupils' self-government, other self-government departments are represented in the educational institution № 52 in Mariupol: pedagogical (pedagogical council, scientific-methodical council, methodical associations, unions, creative groups, clubs, etc.), parents (parents' council, creative workshops), the board of the institution, the board of trustees, alumni associations, volunteer groups, etc.

The task of the headmaster is to create conditions in which the creative potential of teachers could be revealed to the greatest extent and there would be a steady need for hard and productive work. At the same time, it is important for the headmaster to take into account not only the personal abilities of employees, but also their personal motives: needs, interests, priorities.

The modern usage of innovative technologies in an educational institution can be considered as:

- international experience of innovations in scientific education;

- innovative projects, programs, methods and technologies of education in physics, mathematics and technology;

- innovative projects, programs, methods and technologies of education in the social and humanitarian field.

- information and educational space: design and creation of methods and programs for distance and blended learning, electronic textbooks;

- STEM and STEAM-education: problems, prospects and methods of implementation.

We highlight that an effective tool for determining the prospects for development, strategic planning and management is foresight. Ben Martin, a professor at the University of Sussex, defines foresight as a new approach 
to systematic analysis and evaluation of the long-term prospects of science, technology, economics and society to identify strategic research and new technologies that contribute to the greatest socio-economic benefits [9]. This approach is significantly different from traditional technologies. Foresight allows us to reconsider the problems of education, especially in those areas and individual issues related to public participation. The use of foresight technology does not allow teachers to focus on their highly specialized vision of problems and ways to solve them. The main principles of foresight are the following: the future can be created, it depends on joint efforts; the future is variable, it does not flow from the past, but depends on the decisions of participants and stakeholders; we can make predictions about the development of certain areas of activity, but in general the future cannot be predicted reliably, we can prepare for the future as we want to see it. The result of a foresight for an educational institution should be the creation of a so-called "road map", which will allow educational institutions to formulate their missions, goals, curricula and develop strategic development plans taking into account forecast scenarios, possible risks and consequences [2, p. 62].

The innovative project of "Mariupol comprehensive school of I-III grades № 52 of Mariupol city council of Donetsk region" "Let's win together" is a center of physical rehabilitation and kinesiotherapy for children with special educational needs. The purpose of the project: to improve the opportunities for physical and psychological adaptation of pupils; develop the capabilities of the musculoskeletal system in children to acquire the necessary motor skills, improve coordination of movements; develop the ability to behave arbitrarily to overcome psycho-emotional disorders; promotion of sports and a healthy lifestyle. Improve physical and psychological health, involve pupils in a healthy and active lifestyle, develop the need for regular physical activity.

Further development of the project involves holding various sports competitions, festivals for children with special educational needs. Cooperation with the Central Inclusive Resource Centre and the Central Children's and Youth Centre "Victoria" is planned, involvement of children in an active lifestyle and the processes of inclusion and integration in modern society are made.

To determine the effectiveness of the introduction of innovative technologies in management, a questionnaire was developed for the teaching staff. It aims to identify the views of educators on the effectiveness of innovative technologies to ensure the quality of educational services, which is a need for integration into the European educational space, the need to spread innovative learning technologies that promote personal development and self-realization of teachers.

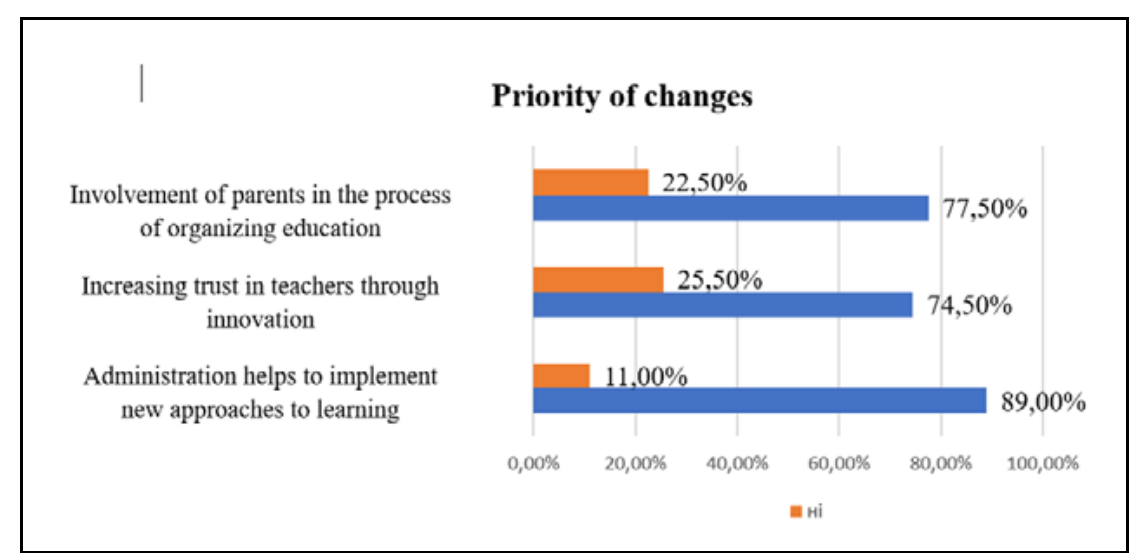

Figure 2. Distribution of answers

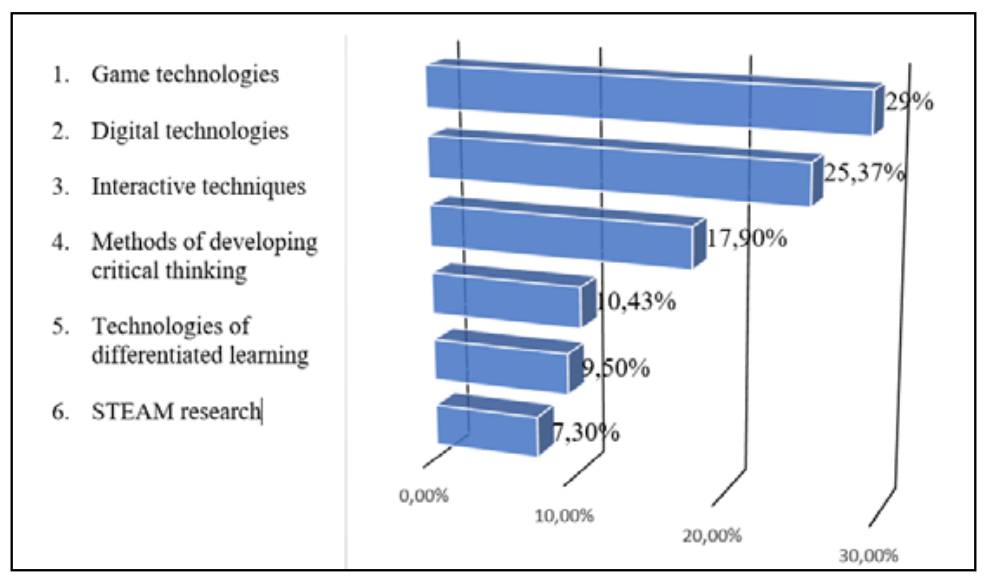

Figure 3. Teachers' answers about using innovative techniques 
Questions are asked about understanding the content of the phenomenon of innovation in the educational institution; study of the ideas of the teaching staff about the importance of the usage of innovations and attitudes to the actions of management with the use of innovative management technologies of the educational institution.

Respondents are almost unanimous that the educational institution is experiencing significant changes because of the usage of innovative technologies. The biggest changes, according to the answers of the survey participants, are in the perception and application of new approaches to teaching and the interest of administration in improving the professional level of teachers. Figure 2 shows the distribution of responses.

Among the methods of innovation that these respondents are ready to use, the most popular are game technologies $(29 \%)$, interactive, digital learning tools $(25.37 \%)$ (see Figure 3 ).

The initiator of ideas and directions of usage of innovative technologies in Mariupol comprehensive school of I-III degrees №52 in 54 cases of answers (or in 49\%) is headmaster, in 32 (or in 29\%) - the project manager, in 17 (or in 16\%) a -specially formed group of teachers, other -7 people (or 6\%) (see table 1). All this, in their opinion, is possible for the development of professional skills and the creation of the image of the educational institution.

Subjects of implementation of innovative projects

Table 1

\begin{tabular}{|c|c|c|}
\hline Questions and answers & Number of answers & Proportion of answers in their total number $(\%)$ \\
\hline \multicolumn{3}{|c|}{ Who initiates or selects the use of innovations in your educational institution? } \\
\hline Headmaster & 54 & $49 \%$ \\
\hline Project manager & 32 & $29 \%$ \\
\hline Specially formed group of teachers & 17 & $16 \%$ \\
\hline Other & 7 & $6 \%$ \\
\hline
\end{tabular}

It should be noted that in general the administration of the educational institution is responsible and interested in the implementation of projects, as it understands that its success (effectiveness of pupils' learning, promoting the image of the institution) determines the future prospects of the educational institution as a whole.

Conclusions. The educational reform provides for the encouragement of teachers to innovate, in particular, that teachers of general secondary education will have favourable conditions and motivating factors for professional growth through innovative technologies in the practice of teaching. The use of innovative management technologies is directly related to: pedagogy of partnership, readiness for innovation, new standards and learning outcomes, autonomy of school and teacher.

Thus, in the implementation of the Concept "New Ukrainian School", the problem of creating an educational space for modern school education, where the growth of social requirements, changing approaches to learning and educational content, the dynamics of scientific and technical developments remain unaccounted becomes relevant. It should be noted that the issue of innovation implementation is primarily a matter of a particular school and depends on the decision of the headmaster, which, on the one hand, is a positive factor, because the headmaster and teaching staff of the school are responsible for creating and implementing innovation.

\section{Bibliography:}

1. Сеїтосманов А., Фасоля О., Мархлєвскі В. Автономія як шлях до ефективного менеджменту школи: Методичні рекомендації. Київ, 2019. 47 c. URL: https://mon.gov.ua/storage/app/media/news/\%D0\%9D\%D0\%BE\%D0\%B2\%D0\%B8\%D0\%BD\% D0\%B8/2020/07/13/2020-07-13-avtonomy.pdf (дата звернення: 25.08.2021).

2. Ганечко I. Г. Форсайт: від прогнозування до формування майбутнього вищої освіти. Інноваційний менеджмент. Харків : ТОВ «Планета-принт», 2016. 197 c. URL: https://knute.edu.ua/file/ODc0Mw=/53ec8a30e688165ab46cb806c8831614.pdf (дата звернення: 25.08.2021).

3. Проєкт закону «Про Стратегію сталого розвитку України до 2030 року». URL: http://search.ligazakon.ua/1_doc2.nsf/link1/ JH6YF00A.html (дата звернення: 25.08.2021).

4. Романчук А. І. Сучасні інноваційні технології управління навчально-виховним процесом у початковій школі. Tеорія $i$ методика управління освітою. Вип. 10, Т. 2. 2019. С. 177-180. URL: http:/www.innovpedagogy.od.ua/archives/2019/10/ part_2/41.pdf (дата звернення: 25.08.2021).

5. Сорочан В. Управління інноваційною діяльністю закладу загальної середньої освіти з інклюзивними класами. Матеріали XI Міжнародного фестивалю педагогічних інновацій. Том 2. Черкаси: КНЗ «ЧОІПОПП ЧОР», 2019. C. 18-21. URL: http://oipopp.ed-sp.net/public/attached_files/ii_tom_0.pdf (дата звернення: 25.08.2021).

6. Arora A., Gambardella A. Bridging the Gap. In A. Aurora and A. Gambardella, eds., From Underdogs to Tigers: The Rise and Growth of the Software Industry in Some Emerging Economies. Oxford, UK: Oxford University Press, 2015. 328 p.

7. Grigoriou K., Rothaermel F. T. Structural microfoundations of innovation: The role of relational stars. Journal of Management. 2014. Vol. 40(2). P. 586-615. DOI: https://doi.org/10.1177/0149206313513612

8. Leger A., Swaminathar S. Innovation Theories Relevance and Implications for Developing Country Innovation. German Institute for Economic Reserch. 2017. P.32.

9. Martin B. The origins of the concept of 'foresight' in science and technology: an insider's perspective. Technological Forecasting and Social Change. 2010. Vol. 77 (9). P. 1438-1447. 


\section{References:}

1. Avtonomiia yak shliakh do efektyvnoho menedzhmentu shkoly/ Ukl. Seitosmanov A., Fasolia O., Markhlievski V.: Metodychni rekomendatsii (2019) [Autonomy as a way to effective school management / Encl. Seitosmanov A., Fasolya O., Markhlevsky V.: Methodical recommendations.] K. 47 s. [in Ukrainian] URL: https://mon.gov.ua/storage/app/media/news/\%D0\%9D\%D0\%BE\% D0\%B2\%D0\%B8\%D0\%BD\%D0\%B8/2020/07/13/2020-07-13-avtonomy.pdf (data zvernennia: 25.08.2021).

2. Hanechko I.H. (2016) Forsait: vid prohnozuvannia do formuvannia maibutnoho vyshchoi osvity. Innovatsiinyi menedzhment. [Foresight: from forecasting to shaping the future of higher education.] Kh.: TOV «Planeta-prynt», 197 s. [in Ukrainian] URL: https://knute.edu.ua/file/ODc0Mw=/53ec8a30e688165ab46cb806c8831614.pdf (data zvernennia: 25.08.2021).

3. Proiekt zakonu «Pro Stratehiiu staloho rozvytku Ukrainy do 2030 roku». [Draft law "On the Strategy of Sustainable Development of Ukraine until 2030"] [in Ukrainian] URL: http://search.ligazakon.ua/1_doc2.nsf/link1/JH6YF00A.html (data zvernennia: 25.08.2021)

4. Romanchuk A. I. (2019) Suchasni innovatsiini tekhnolohii upravlinnia navchalno-vykhovnym protsesom u pochatkovii shkoli [Modern innovative technologies for managing the educational process in primary school] Teoriia i metodyka upravlinnia osvitoiu. Vypusk 10. T. 2. 2019, S.177-180. [in Ukrainian] URL:http:/www.innovpedagogy.od.ua/archives/2019/10/part_2/41.pdf (data zvernennia: 25.08.2021).

5. Sorochan V.(2019) Upravlinnia innovatsiinoiu diialnistiu zakladu zahalnoi serednoi osvity z inkliuzyvnymy klasamy [Management of innovative activity of general secondary education institution with inclusive classes] Materialy XI Mizhnarodnoho festyvaliu pedahohichnykh innovatsii / [Upor. Nazarenko H. A.]. [in Ukrainian] Tom 2. Cherkasy: KNZ «ChOIPOPP ChOR», S. 18-21. URL: http://oipopp.ed-sp.net/public/attached_files/ii_tom_0.pdf (data zvernennia: 25.08.2021).

6. Arora A. and Gambardella A. Bridging the Gap. In A. Aurora and A. Gambardella, eds., From Underdogs to Tigers: The Rise and Growth of the Software Industry in Some Emerging Economies. Oxford, UK: Oxford University Press, 2015. 328 p.

7. Grigoriou, K., \& Rothaermel, F. T. (2014). Structural microfoundations of innovation: The role of relational stars. Journal of Management, 40(2): 586-615. DOI: https://doi.org/10.1177/0149206313513612

8. Leger A. Innovation Theories Relevance and Implications for Developing Country Innovation/ Leger A. S. Swaminathar / German Institute for Economic Reserch. 2017. P.32.

9. Martin, Ben. The origins of the concept of 'foresight' in science and technology: an insider's perspective. Technological Forecasting and Social Change, 2010. 77 (9). pp. 1438-1447.

Тимофсєва І. Б., Нетреба М. М., Мойсеснко Р. М., Хаджинова І. В. Сутнісні характеристики використання інноваційних технологій у закладах освіти нової украйнськой иколи

У статті розкрито використання інновачійних технологій в управлінні закладом загальної середньої освіти; обгрунтовано впровадження інноваційних технологій в управлінську діяльність керівника закладу освіти. Висвітлено управлінські проблеми задля забезпечення якості надання освітніх послуг та розглянуто сутнісні характеристики впровадження інновачійних технологій в умовах закладу освіти. Охарактеризовано зміст, інструментарій ефективних інноваційних управлінських технологій у закладах освіти: будування прогнозів, стимулювання педагогів, зміна структури школи, комплексне вирішення проблеми та інше.

Важливе значення у запровадженні інноваційних технологій управління має децентралізація процесу керівництва школою. Встановлено, що продуктивним застосуванням інноващій в управлінні закладом освіти є участь усіх учасників освітнього процесу в міжнародних проєктах. Після проведення анкетування доведено, щзо застосування інноваційних технологій управління керівником закладу освіти вимагає досконалого вивчення інноваційного потениіалу педагогів та особливостей інновачійного управління закладом освіти. Задля забезпечення якості надання освітніх послуг виявлено нагальну потребу в застосуванні педагогами інновачійних технологій у навчанні.

Проблема дослідження трунтується на практичному прийомі, в межах якого інновачії управління розглядаються як застосування прийомів інновачійної діяльності педагогів задля створення іміджу освітнього закладу. Інноваиї відіграють в управлінні закладом загальної середньої освіти роль переходу важливості суб'єктів прийняття рішень про запровадження інновацій менеджменту. Використання форсайту, аналізу міжнародного досвіду закладів освіти дає змогу результативно визначити необхідність упровадження інноваційних технологій управління закладом освіти.

Ключові слова: інновація, інноваційні технологї, управління закладом освіти, керівник школи. 